\title{
Characteristics of subglacial drainage systems deduced from load-cell measurements
}

\author{
Gaute LAPPEGARD, ${ }^{1}$ Jack KOHLER, ${ }^{2}$ Miriam JACKSON, ${ }^{3}$ Jon Ove HAGEN ${ }^{1}$ \\ ${ }^{1}$ Department of Geosciences, University of Oslo, PO Box 1047 Blindern, N-0316 Oslo, Norway \\ E-mail: gautelap@geo.uio.no \\ ${ }^{2}$ Norwegian Polar Institute, Polar Environmental Center, N-9296 Tromsø, Norway \\ ${ }^{3}$ NVE, Hydrology Department, Glacier and Environmental Hydrology Section, PO Box 5091 Majorstua, N-0301 Oslo, Norway
}

\begin{abstract}
Rock tunnels beneath Engabreen, northern Norway, permit access to the ice-bedrock interface beneath a $210 \mathrm{~m}$ thick glacier. Eight load cells have been installed in the bedrock of the glacier sole along a $22 \mathrm{~m}$ transect. With some interruptions, the load cells have been logged at $15 \mathrm{~min}$ intervals since December 1992; here we analyse the records until 2003. Load-cell signals measure stresses acting normal to the bedrock, and usually log the pressure of the thin water film between the basal ice and the bed. Occasionally there are distinct pressure events, characterized by short-lived (hours) local minima, often followed by a maximum before decaying to background load-cell pressure. The amplitudes of these pressure events are of the order of 0.01-1 MPa and depend on the placement of the sensor and the state of the subglacial drainage system. We identify winter and summer pressure regimes. The winter regime is characterized by few pressure events of large pressure amplitude influencing all load cells. A lag of 0-6 days is observed between surface forcing (rain) and pressure events during winter. The summer regime typically has periods of daily pressure events of low amplitude. No delay is seen between surface forcing and pressure events during the summer regime. In summer, the onset of a pressure event is correlated with a local maximum of the derivative of the subglacial discharge record, whereas no such relation is found during the winter regime. The transition from winter to summer (May/June) is easily detectable and is strongly correlated with a rapid increase in subglacial discharge and the transition to a dominating R-channel system. The autumn transition is less clearly defined, but has usually occurred by the beginning of November. Stress bridging, an increase in bed pressure at the edge of low-pressure channels, is recorded during the summer regime. Water pressures at the bed are connected or unconnected to the drainage system. Pressure increases in the connected system, beyond local normal stress values, lead to an uplift of the connected system and a pressure drop in the unconnected system. The occurrence of pressure events is determined by the capacity of the drainage system. Uplift is controlled by local normal stress values and not mean ice-overburden pressure.
\end{abstract}

\section{INTRODUCTION}

In glaciology, pressure variations in boreholes are frequently used to interpret the behaviour of the subglacial drainage system and glacier dynamics (e.g. Iken and Bindschadler, 1986; Hubbard and others, 1995; Smart, 1996; Stone and Clarke, 1996; Tulaczyk and others, 2000). Gordon and others (2001) point out the problems related to borehole observations and suggest a variety of techniques to improve the measurements. There are, however, many limitations to instrumentation using boreholes from the surface, including challenges in placement of instrumentation, an inability to know much about the bed environment and problems associated with ice displacement, which will change the position of the instrumentation.

An alternative to instrumentation of the glacier bed through surface boreholes is to access the bed directly. This has been done by setting up experiments from transverse subaerial cavities at the glacier edge (Echelmeyer and Wang, 1987; Rea and Whalley, 1994), although the ice thickness at the experimental site is typically limited in this case to a few tens of metres.

Access to significantly deeper ice can be obtained via bedrock tunnels drilled in connection with hydroelectric projects. At present there are only three such facilities drilled in the world; nevertheless, research results from these have contributed considerably to the understanding of subglacial processes. Vivian and Bocquet (1973) documented the existence of linked cavitation transverse to the direction of glacier flow underneath Glacier d'Argentière, France (ice thickness: $100 \mathrm{~m}$ ). Hagen and others (1993) measured stoss and lee side effects, including temperature, on a roche moutonnée mounted underneath Bondhusbreen, Norway (ice thickness: $160 \mathrm{~m}$ ). Cohen (2000) used instrumentation data from Engabreen, Norway, and finite-element modelling to estimate the softness parameter in the flow law for ice. Iverson and others (2003) measured shear traction of 60$200 \mathrm{kPa}$ on a smooth rock bed underneath Engabreen, indicating that debris-bed friction should not be neglected in sliding theories. Lappegard and Kohler (2005) pressurized the bed in excess of ice-overburden pressure to reveal the characteristics of the flow-rate dependent basal drainage system.

In this paper, we present 11 years of load-cell measurements recorded at the bed beneath $210 \mathrm{~m}$ of ice at Engabreen. Although the load cells are distributed over a limited area of the bed, they give important information about the nature of the subglacial drainage system, and how pressure at the glacier sole varies in response to the evolution of the subglacial hydraulic system. 


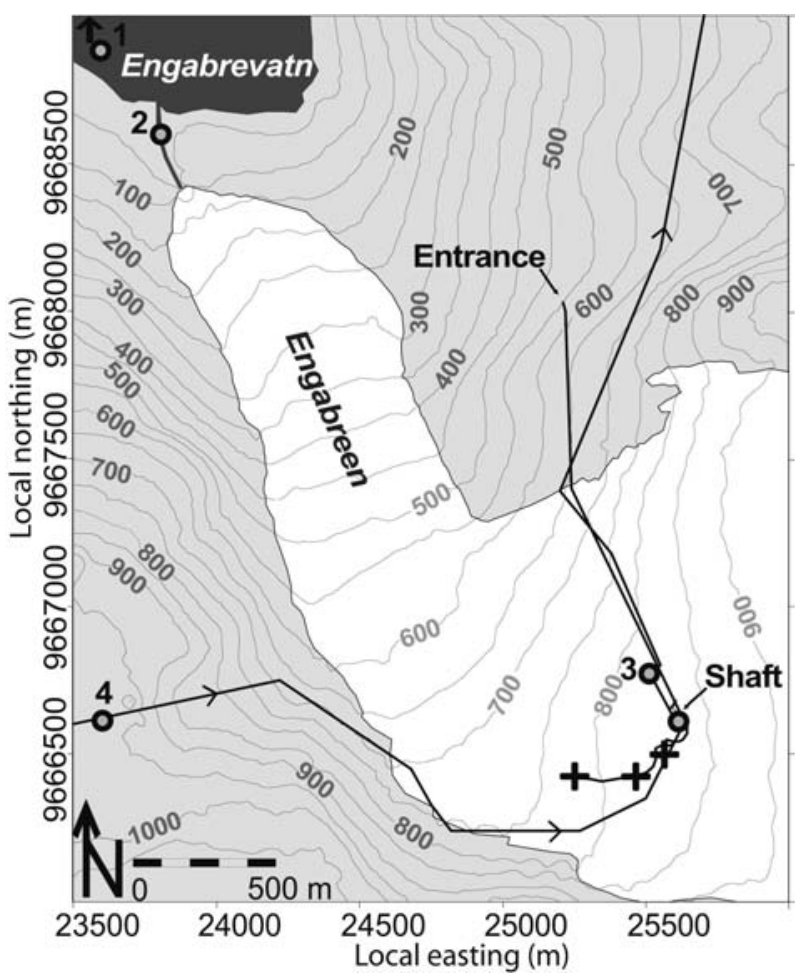

Fig. 1. Map of Engabreen (1995) with tunnel system (dark lines; water flow direction indicated with arrows). Black circle ('Shaft') indicates the research tunnel leading into the ice (study area). Black circles with numbers show the placement of the four discharge stations, while three crosses show the active subglacial intakes.

\section{FIELD SITE}

Engabreen is a hard-bedded temperate outlet glacier of the Svartisen ice cap, northern Norway (Fig. 1). Engabreen drains ice from a high plateau at roughly $1200-1600 \mathrm{~m}$ a.s.I., down a narrow valley, to terminate at $15 \mathrm{~m}$ a.s.I. Tunnels have been excavated in the bedrock beneath Engabreen as part of a hydropower project. Within the tunnel system is the Svartisen Subglacial Laboratory, a facility whose main feature is access to the glacier bed via a purpose-built access shaft.

The inclined access shaft goes up from the main tunnel level $(600 \mathrm{~m}$ a.s.l.) to within a few metres of the ice-rock interface $(630 \mathrm{~m}$ a.s.l.); at this location the overlying ice is $210 \mathrm{~m}$ thick. From this point, entry to the basal ice is gained through two short shafts, one horizontal the other vertical; both are sealed with protective doors to keep ice from flowing into the access tunnels. By removing the doors and using a hot-water spraying system, it is possible to melt 15$20 \mathrm{~m}$ long ice-tunnels along the hard bed to install instrumentation (Iverson and others, 2003), expose the basal ice for documentation (Jansson and others, 1996) and survey the local bed topography.

Three subglacial intakes (Fig. 1) are situated west of and slightly down-glacier of the access shaft, at distances of 110 , 160 and $420 \mathrm{~m}$. The elevation of the intakes is around $670 \mathrm{~m}$ a.s.l., and the ice thicknesses are around $200-210 \mathrm{~m}$. Above the entire area the glacier is about $1.5 \mathrm{~km}$ wide, its surface slope is about 8 and the mean annual surface velocity is about $0.8 \mathrm{~m} \mathrm{~d}^{-1}$ (Kohler, 1998).

The local bed topography around the access shaft is dominated by transverse metre-scale undulations. The general bed slope at the site is close to 10 , and the general ice-flow direction is $240^{\circ}$. Bed separation (cavitation) has
Table 1. Load-cell orientation

\begin{tabular}{lcrc}
\hline Load cell & Azimuth & Tilt & Level \\
& & & ma.s.l. \\
& & & \\
\hline LC 6 & $140 \pm 10^{\circ}$ & $12^{\circ}$ & 630.6 \\
LC 4 & $170 \pm 10^{\circ}$ & $125^{\circ}$ & 631.7 \\
LC $2 \mathrm{a}$ & $170 \pm 10^{\circ}$ & $13^{\circ}$ & 632.6 \\
LC $2 \mathrm{~b}$ & - & $0^{\circ}$ & 632.5 \\
LC 7 & $190 \pm 10^{\circ}$ & $13^{\circ}$ & 630.9 \\
LC $1 \mathrm{e}$ & $180 \pm 10^{\circ}$ & $31^{\circ}$ & 630.7 \\
LC $97-1$ & $250 \pm 10^{\circ}$ & $9^{\circ}$ & 630.7 \\
LC 97-2 & $250 \pm 10^{\circ}$ & $14^{\circ}$ & 630.6 \\
& & & \\
\hline
\end{tabular}

not been observed during the melting of ice tunnels, but a 'brown skin' is apparent on lee sides in several locations, indicating the presence of water-filled cavities (Iken and Truffer, 1997).

\section{INSTRUMENTATION}

\subsection{Vibrating-wire load cells}

In December 1992, eight GEONOR P-105 earth pressure cells were installed flush with the bedrock. These vibratingwire load cells, originally developed for dam and offshore constructions, are designed to measure the total hydrostatic pressure acting normal to a pressure plate, $0.23 \mathrm{~m}$ in diameter. The local compressive strain induced in a loadcell plate is measured as a frequency change in a vibratingwire sensor. The calibrated range of the vibrating-wire load cells is $0-5 \mathrm{MPa}$. Each cell has been individually tested and calibrated in hydrostatic conditions at the factory. The manufacturer's quoted error for the load cells used at Engabreen is no more than $0.1 \%( \pm 5 \mathrm{kPa})$ of the test load. Cables transmit the pressure signal through boreholes leading from the ice-bedrock interface down to the underlying tunnel system and to a laboratory building, where a Campbell Scientific CR10 data logger and an external storage module are located.

The main advantage of using vibrating-wire load cells is the long-term stability of the devices (DiBagio, 2003). We account for any long-term drift in the load cells' zero pressure calibration during field campaigns by melting tunnels in the basal ice directly over the load cells, thus removing the load on them. The drift, if any, is evenly distributed over the interval since the previous calibration check. Most of the observed drift in calibration seems to have occurred during the first years after installation, a wellknown artefact of vibrating-wire load cells (DiBagio, 2003).

The load cells are mounted along a $22 \mathrm{~m}$ transect almost perpendicular to the main ice-flow direction in the vicinity of the access shaft (Fig. 2) (Jackson, 2000). The load cells are installed on the stoss and lee sides of bumps, inside bedrock overhangs and on flat terrain (Table 1). Since their installation the load cells have measured pressure variations at 15 min intervals. There are a limited number of gaps in the record due to various interruptions. As of 2004, six of the eight load cells installed were still operative.

The use of load cells in glaciology is relatively limited, with published data from only three glaciers: Bondhusbreen (Hagen and others, 1993), Engabreen (Cohen, 2000; Cohen and others, 2000; Iverson and others, 2003; Lappegard and 


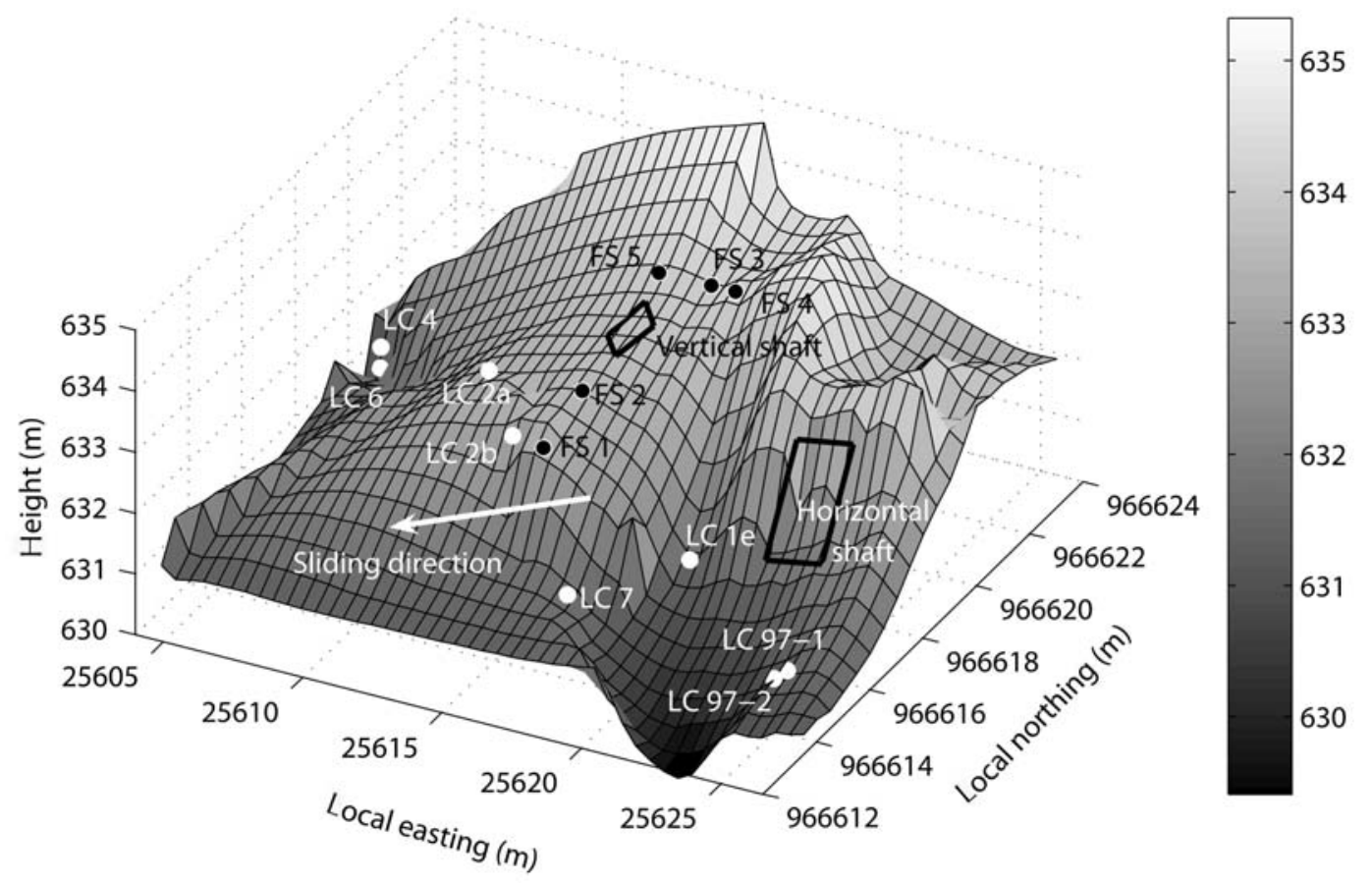

Fig. 2. Three-dimensional view of the glacier bed at the study site. 'Vertical shaft' and 'Horizontal shaft' indicate the two entrances giving access to the glacier bed. White circles are load cells mounted flush with the glacier bed: LC 4, 6, 2a, 2b, 7, 1e, 97-1 and 97-2. Black circles are locations of tunnel boreholes: FS 1-FS 5.

Kohler, 2005) and Glacier d'Argentière (Boulton and others, 1979). Although load cells are seldom used, they offer several advantages. The main technical advantage is the possibility of continuous logging of pressure at the same point on the bed. This eliminates the need to estimate ice flow to correct for displacement of the instrument relative to the start point, as is often the case when using instruments installed in the deforming ice.

\subsection{Pressure transducers}

Throughout the bedrock tunnel system there are many pilot boreholes drilled from the tunnel up to the glacier bed. These tunnel boreholes, used originally to confirm bed topography during tunnel construction, are $<0.1 \mathrm{~m}$ in diameter. Observations made during our field campaigns show that these tunnel boreholes can suddenly drain water from the glacier bed throughout the year. When observed, such events are seen to last for periods of hours to days.

From the research shaft, five such rock boreholes lead up to the glacier bed (FS 1-FS 5; Fig. 2). The boreholes are $39 \mathrm{~mm}$ in diameter, except FS 3, which is $64 \mathrm{~mm}$. Between visits to the SSL, we often see evidence that draining events have occurred, as sediments and small rocks have been deposited on the tunnel floor in the access shaft directly under the boreholes. If we happen to be in the tunnel at the time of a draining event, we block the active boreholes using rubber packers attached to steel pipes which are, in turn, connected to pressure transducers. We use Stiko PTX-2 pressure transducers (4-20 mA output, 0-3 MPa pressure range) connected to a Campbell Scientific CR10 logger.

The entire pipe set-up has shut-off valves so that we can drain the boreholes or measure water pressure, as desired. When closed, this set-up effectively seals the boreholes and allows direct measurement of water pressure in whichever drainage system is encountered at the point where the borehole crops out on the bed. These direct records of water pressure differ from the load-cell records in a way that allows us to compare and discuss the differences between several basal hydraulic systems.

We have tried to keep these boreholes logging over longer time intervals (months), but they become filled with sediment and ice from the basal ice passing over the borehole, resulting in interruption of the signal. Therefore, the rock boreholes are left open and unpacked after each field campaign.

\subsection{Water-discharge gauging stations}

Discharge is logged at four different streams around and underneath Engabreen (Fig. 1). Station 1 logs the outlet stream of the proglacial lake Engabrevatn (13 ma.s.l.). The lake takes some water from the unglacierized portion of the valley, but its main source is from the glacier. Station 2 logged discharge in the proglacial stream at the snout of the glacier (20 ma.s.I.) until 1997, at which time it had to be removed due to a glacier advance (Haakensen, 1998). No replacement has been installed. Stations 3 and 4 are placed in the tunnel system (600 ma.s.l.). Station 3 logs discharge downstream of the confluence of two separate tunnel systems, one from the Engabreen subglacial intakes (marked with ' + ' on Fig. 1) and the other from subaerial intakes in another watershed (station 4; Fig. 1). Station 4 was installed in late 1997. We can calculate the subglacial discharge routed into the three subglacial intakes from 1998 onward by subtracting the station 4 record from that of station 3 .

\subsection{Weather stations}

Meteorological data are obtained from the Norwegian Meteorological Institute's station at Glomfjord (39 ma.s.I.), $10 \mathrm{~km}$ east of Engabreen, and from the Norwegian Water Resources and Energy Directorate (NVE)'s meteorological 

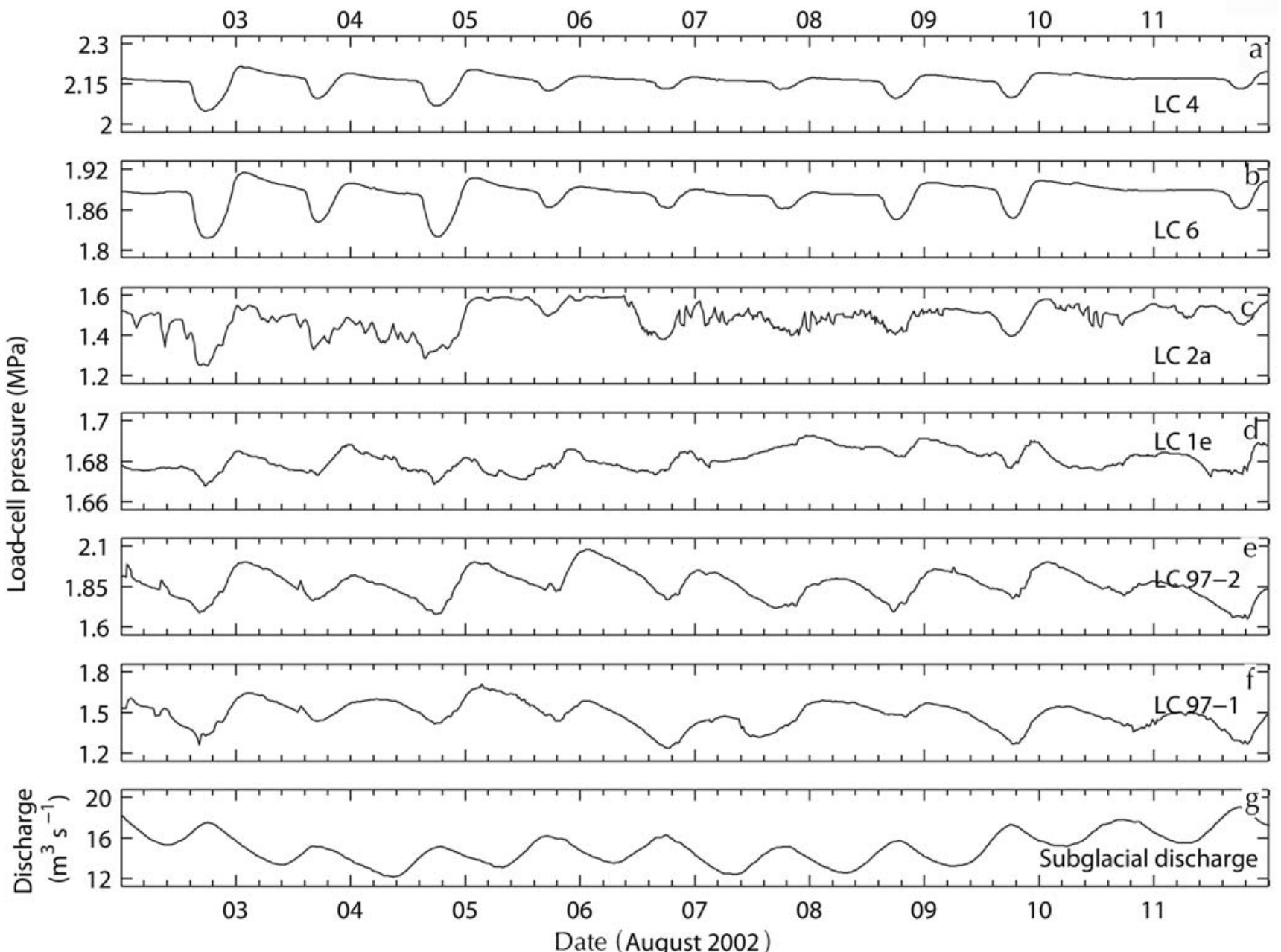

Fig. 3. (a-f) Diurnal load-cell pressure events forced by diurnally changing surface water input during 10 days in August 2002. (g) Subglacial discharge. Note the different $y$-axis scales.

station at Skjæret (1354 m a.s.I.), a nunatak $7 \mathrm{~km}$ distant from the subglacial intakes, and close to the top of Svartisen. From the Glomfjord station we obtain daily mean air temperature and daily precipitation. However, the record does not distinguish whether the measured precipitation occurs as snow or as rain. From Skjæret station we obtain hourly air temperature. The Skjæret station has been active since 1995, but there are few data from the first 4 years of operation; since 1999, however, there are just minor data gaps. Using one or both stations we can estimate a daily lapse rate for Engabreen, to get an indication of whether precipitation measured at Glomfjord would occur as rain or snow on the glacier surface above the intakes. The distance from Glomfjord to Svartisen, the maritime climate and the strong onshore winds at Svartisen mean that this simple approach may not always predict the precipitation amount or type correctly. It is, however, the only way to determine possible surface inputs to the Engabreen drainage system.

\section{OBSERVATIONS}

The characteristic response of a load cell is affected in large part by the placement and orientation of its pressure plate relative to the ice-flow direction (Table 1). Despite the different load-cell orientations, some pressure signals are detected by all load cells, albeit with different magnitudes; we term such events 'global'. Other events are only detected at one or some of the load cells; we refer to these events as 'local'. Furthermore, there are two distinct subglacial pressure regimes as deduced from the load-cell records: winter and summer. We now summarize the characteristics of the various events and describe how they differ between the seasons. Our observations are consistent in the sense that they have occurred multiple times throughout the 11 year record.

\subsection{Pressure events}

The most obvious events in the load-cell records are distinct, short-duration pressure minima, usually followed by sharp peaks (Fig. 3). These pressure events never last more than 12 hours. During any one event the individual load-cell records do not necessarily vary simultaneously; typically LC 4 and LC 6 have relatively sharp onsets, whereas the other load-cell records exhibit more gradual changes (Fig. 3). Pressure events can occur either daily, during sunny periods with diurnally varying surface meltwater input, or as singular events, in connection with rapidly increasing subglacial discharge following rainfall at the surface.

Pressure events recorded during the summer season typically start around mid-afternoon, with a rapid decrease in pressure ending at a minimum typically 4-5 hours later, followed by an increase that ends around midnight at higher 

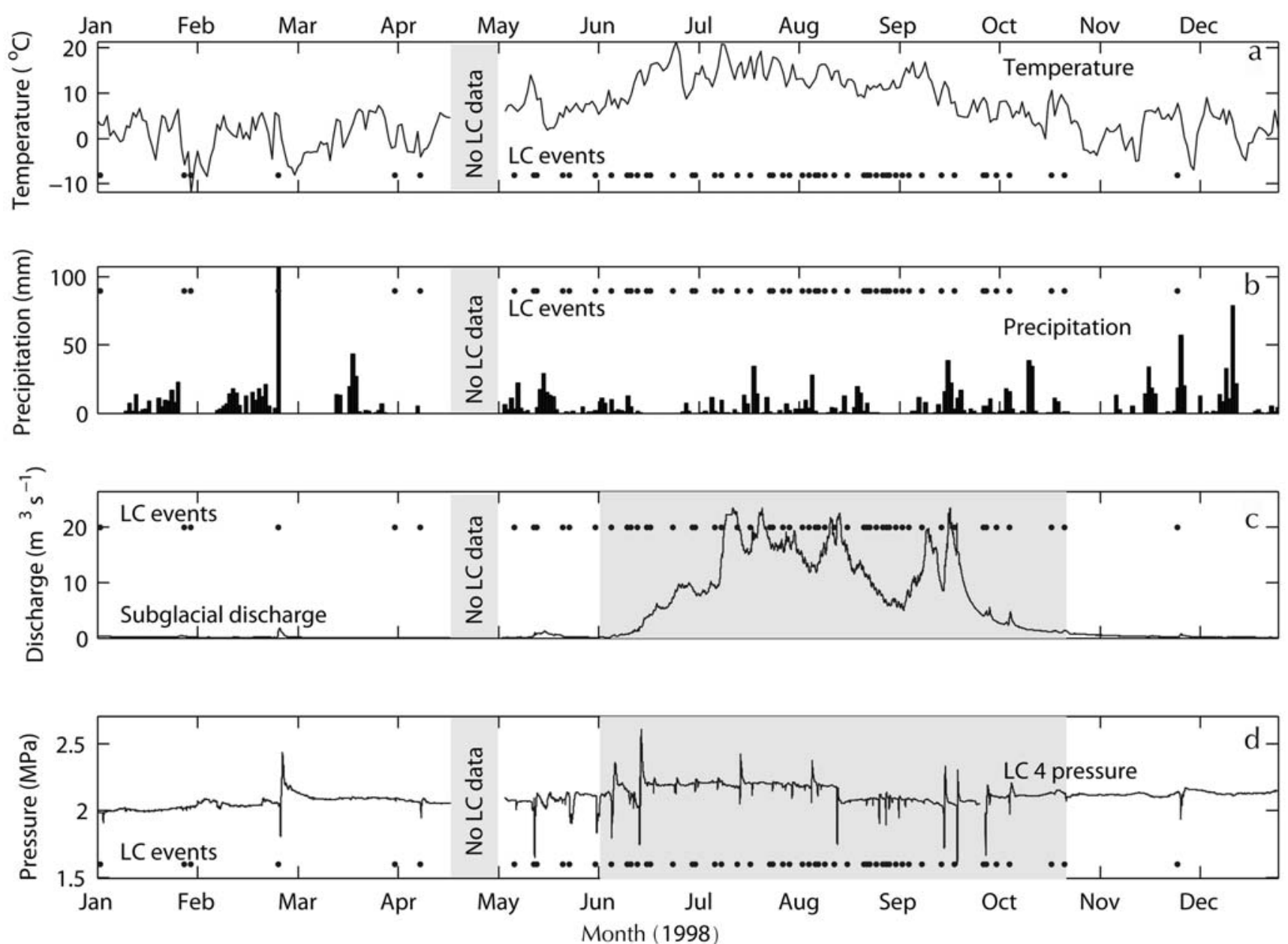

Fig. 4. Indication of seasonally dependent pressure regimes. (a) Global pressure events (black dots) and temperature at Glomfjord. (b) Global pressure events (black dots) and precipitation at Glomfjord at temperatures $>0{ }^{\circ} \mathrm{C}$ (rain). (c) Global pressure events (black dots) and subglacial discharge. Period where the onset of pressure events and local maxima of the derivative of the subglacial discharge record coincide is shaded grey. (d) Global pressure events (black dots) and load-cell 4 (LC 4) pressure. Grey shaded period as in (c). Period with missing loadcell data is marked with a light grey column in all three plots.

pressures than the initial pre-event pressure. The pressure then decreases gradually back to the pre-event level by early morning. During winter no such regularities are seen in the load-cell records regarding pressure events. They do occur during winter, but are lesss frequent and typically have a larger amplitude.

To identify these events in the load-cell records, we resample all records at 1 hour intervals and define a pressure event as a change in the first derivative of the load-cell signal from $-c$ to $c$ over a time interval $<12$ hours. Here $c$ is a load-cell signal amplitude-dependent constant where $c \in[2,17] \mathrm{kPah}^{-1}$. LC $2 \mathrm{a}$ has the highest threshold value and LC 6 the lowest. In total we found 373 global pressure events between 1993 and 2003.

There is a clear change in the frequency of pressure events through the year, with fewer events during winter, increasing activity in spring, highest frequency in summer and fewer events during autumn (Fig. 4). Pressure amplitudes on the various load cells during a single event can vary from $<10 \mathrm{kPa}$ to $>1 \mathrm{MPa}$. We have plotted the pressure amplitudes of the LC 4 record for all 373 events by month in a box-andwhisker plot (Fig. 5). The highest frequency of low-amplitude events is found during the summer months June-August, but this is also the time with the largest number of highamplitude events. Pressure events during winter (DecemberApril) usually have more consistently large amplitudes.

During periods of high discharge (summer), the onset of pressure events seems to occur at roughly the same time as the maximum in the first derivative of the discharge (Fig. 6). Of course, not all first derivative maxima have a corresponding pressure event during the summer, but this contrasts with the case of late autumn, winter and spring, when there is no clear relation between pressure events and the derivative of the subglacial discharge. In Figure $4 c$ and $d$ we indicate the period for which pressure events coincide with maxima in the derivative of the subglacial discharge.

The onset of the summer regime is easy to detect in the load-cell record as several large-amplitude pressure events occur simultaneously with a dramatic increase in the subglacial discharge, which typically increases by two orders of magnitude over a few days in spring (May-June). The transition between the summer and winter regimes is difficult to pin down exactly. The frequency of pressure events throughout the autumn is low relative to summer, so several days or weeks can pass between pressure events. We interpret the start of the stable winter regime to be gradual 


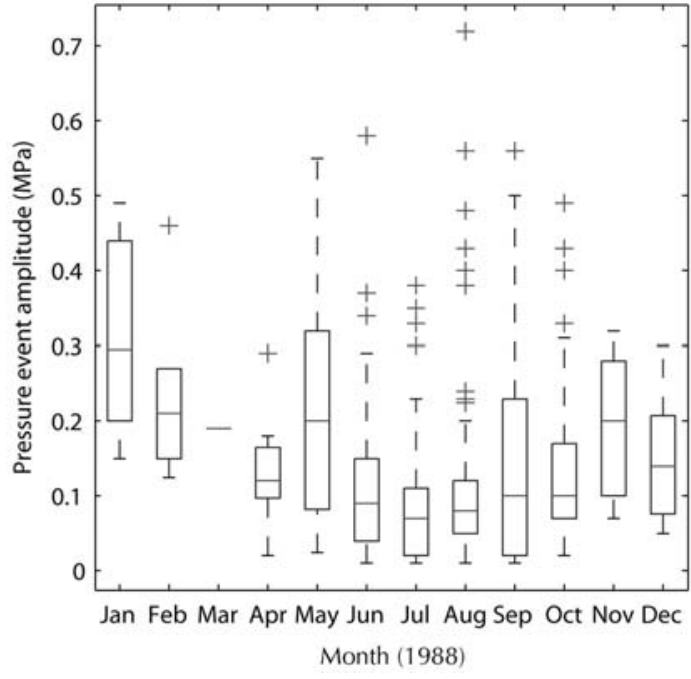

Fig. 5. Amplitudes of all global pressure events on LC 4 grouped in months for the years 1993-2003 plotted as boxes and whiskers. The boxes have lines at the lower-quartile, median and upper-quartile values. The whiskers are lines extending from each end of the box to show the extent of the rest of the data. Outliers are data with values beyond the ends of the whiskers. Whiskers extend from the box out to the most extreme data value as a function of the interquartile range of the sample.

and smooth without any sign in the load-cell record of a definite switch between the two regimes. The transition has usually occurred by the end of October/beginning of November.

Considering all global pressure events during the winter months December-April for all 11 years, we count 30 global pressure events. Of these 30 pressure events, all but one could be correlated to either high temperatures, rain or a significant discharge peak in subglacial discharge. Pressure events that occur during winter are exemplified by an event in April 2000 (Fig. 7). Four warm days at the end of March 2000 culminating in a rain event resulted in a gradual discharge response at the three logging stations at Engabreen. We infer this to be due to the direct runoff. Four days later, during which time there was clear, cold weather and presumably no further surface water input, there was a peak in subglacial discharge and a global pressure event (Fig. 7). The previous pressure event had occurred more than a month earlier, so we can assume that both the sub- and englacial drainage systems were poorly developed prior to the March event.

Because of the maritime climate at Engabreen, rain or surface melt can occur at any time of the year, and at nearly all elevations. Not all winter surface inputs can be correlated with a recorded pressure event but, when they can, the delay between surface water input and the observed pressure event varies from 0 to 6 days, depending on the time elapsed since the last rainfall or surface melt episode. By comparison, summer pressure events occur while the subglacial discharge signal is rising, although, as stated, a rise in discharge is not necessarily accompanied by a corresponding global pressure event.

\subsection{High-pressure outbursts}

The onset of the spring melt usually occurs in May. Highpressure outbursts from a number of tunnel boreholes
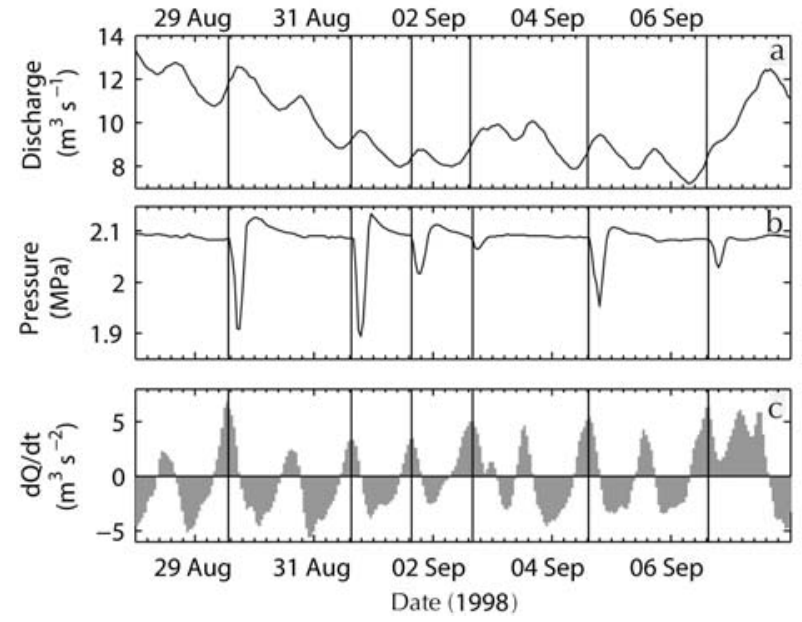

Fig. 6. Subglacial discharge (a), pressure record for LC 4 (b) and first derivative of subglacial discharge (c), August-September 1998.

herald the arrival of the first melt at the bed. Water flows out of boreholes during the first few days after the surface runoff starts in earnest above the intakes ( $840 \mathrm{~m}$ a.s.l.). At the same time, there is a small increase in discharge flowing through the main subglacial intakes in the tunnel. The discharge from such borehole outbursts is measured to be $<0.05 \mathrm{~m}^{3} \mathrm{~s}^{-1}$, and is thus still relatively minor compared with the discharge from the subglacial intakes. Some days later, the number of 'connected' boreholes decreases. After a further few days the discharge in the subglacial intakes begins to increase significantly while the tunnel boreholes largely cease to yield water. This chain of events observed at Engabreen is similar to observations made in a comparable tunnel system at Bondhusbreen (Hagen and others, 1983).

The highest incidence of observed outbursts occurs during spring and summer. Several outburst events have been logged with pressure transducers installed in research tunnel boreholes, as described in section 3.2. The usual water-pressure range in these blocked boreholes during outburst events is less than the overburden pressure, typically 1-1.5 MPa. In many cases, tunnel borehole outbursts are accompanied by distinctive patterns in the loadcell records. On three occasions, a water-pressure increase in one or several of these blocked and logged boreholes comes with a corresponding pressure drop at one or several load cells. Common for these three events is that the local load-cell pressure events began to occur before the tunnel borehole pressures had reached the mean ice-overburden pressure (1.84 MPa).

One such water-pressure increase was recorded in May 1998 in borehole FS 3 (Fig. 8); water pressure rose from 1.3 $\mathrm{MPa}$ to $>1.8 \mathrm{MPa}$ in 2 hours. The water pressure in the borehole never reached the mean ice-overburden pressure of 1.84 MPa, but two load cells (LC 97-1 and 97-2), located approximately $10 \mathrm{~m}$ away from FS 3 (Fig. 2), logged a local pressure event whose onset began when the effective pressure $\left(p_{\mathrm{i}}-p_{\mathrm{w}}\right.$, where $p$ is pressure and the subscripts $\mathrm{i}$ and $w$ indicate ice and water) was $<47 \mathrm{kPa}$. At this point, load-cell pressures dropped $65 \mathrm{kPa}$ on LC 97-2 and $134 \mathrm{kPa}$ on LC 97-1. The water pressure remained at this high value, though below mean flotation level, for $>1$ hour before decreasing to the pre-event pressure of 1.3-1.4 MPa. 


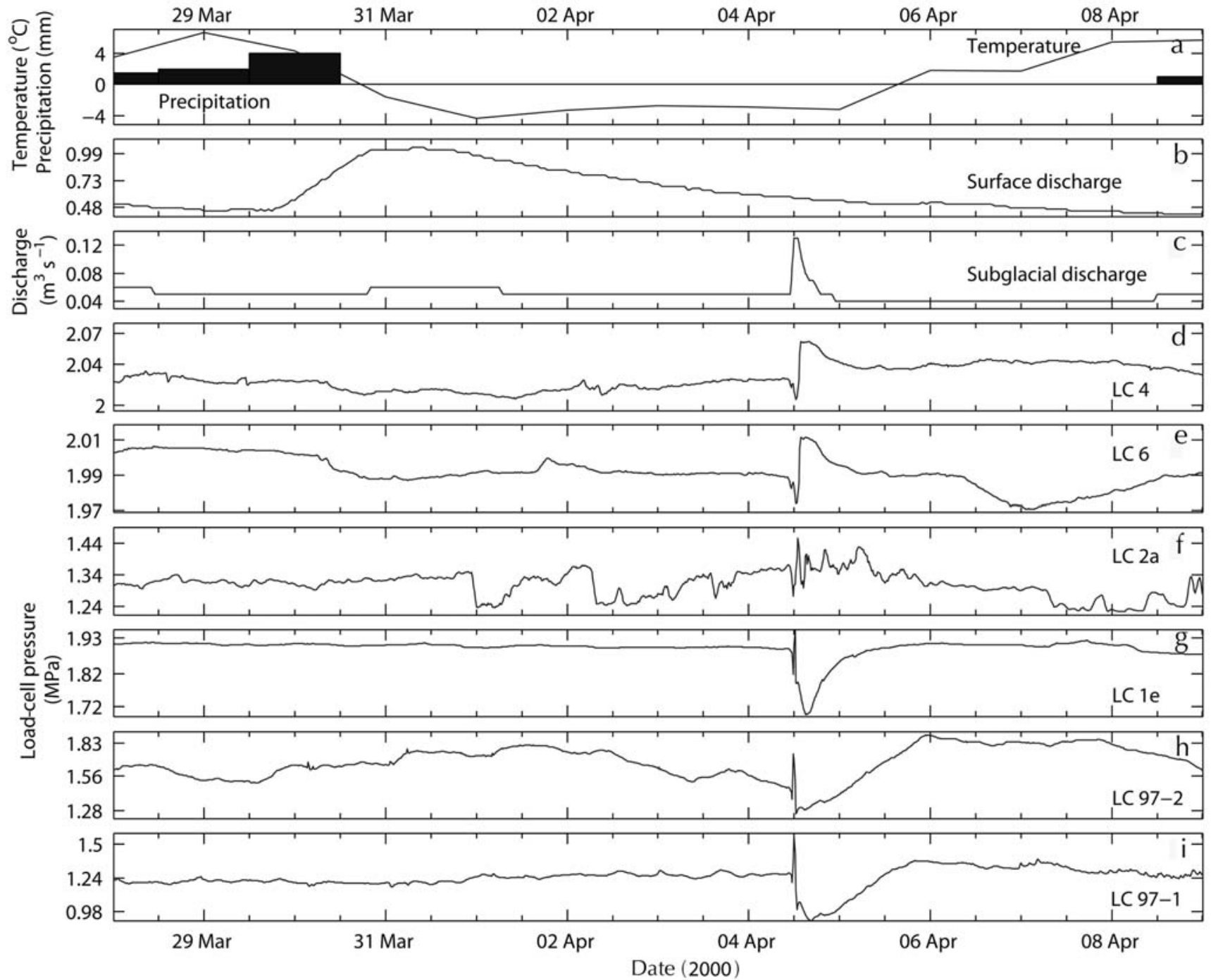

Fig. 7. Four days of surface melt and rain forces a delayed subglacial discharge peak and a pressure event, March-April 2000. (a) Temperature and precipitation. (b) Surface discharge at Engabrevatn (station 1). (c) Subglacial discharge. (d-i) Individual load-cell records. Note the different $y$-axis scales.

\subsection{Low-pressure periods}

Occasionally, we find periods during which the load cells register extremely low pressures, usually on either one or both of LC 97-1 and 97-2. The distance between LC 97-1 and $97-2$ is $<0.5 \mathrm{~m}$, and they are placed on a line parallel to the local sliding direction (Fig. 2). Typically, the pressure drops from the local background pressure down to zero or a few kilopascals, and remains at low pressures over periods lasting hours to weeks.

Low-pressure intervals usually occur during the summer months, but we have recorded one in winter (JanuaryFebruary 2002) following a heavy rainstorm. This winter low-pressure interval lasted 7 days on LC 97-1 and the pressure fluctuated around $30 \mathrm{kPa}$.

An example of a summer low-pressure period is shown in Figure 9. In June 2003, subglacial discharge doubled in 1 day (Fig. 9g), and four of the six load cells had pressure events (Fig. 9a-d). Meanwhile, pressure on the remaining two load cells, LC 97-1 and 97-2, dropped close to atmospheric conditions (Fig. 9e-f). Pressure began to increase at 97-1 after 8 hours, eventually reaching a high of $2.3 \mathrm{MPa}$ (recall mean ice overburden is $1.84 \mathrm{MPa}$ ). The pressure finally stabilized around $1.7 \mathrm{MPa}$, still $0.4 \mathrm{MPa}$

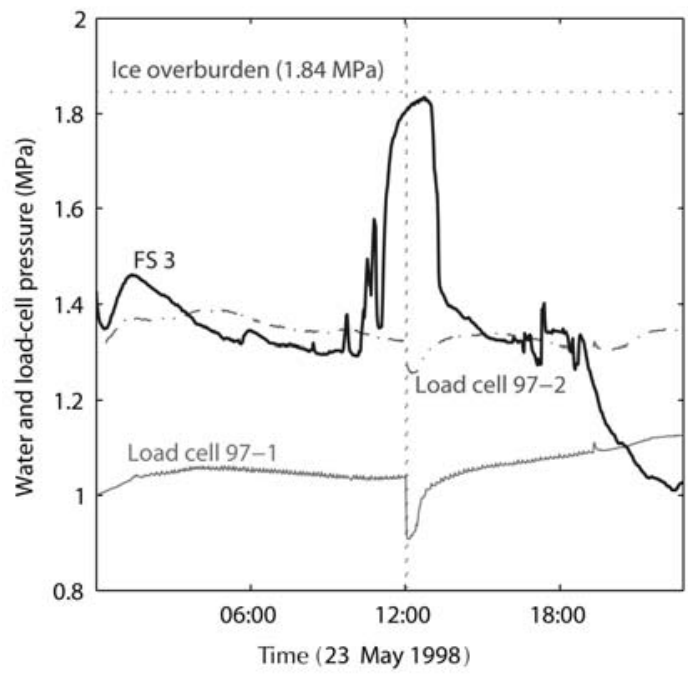

Fig. 8. Natural water-pressure pulse recorded in the connected borehole FS 3 (solid dark line) triggered two local load-cell pressure events on LC 97-2 (dash-dotted line) and 97-1 (light solid line) during melt turn-on in May 1998. Mean ice-overburden pressure indicated as light dotted line. 

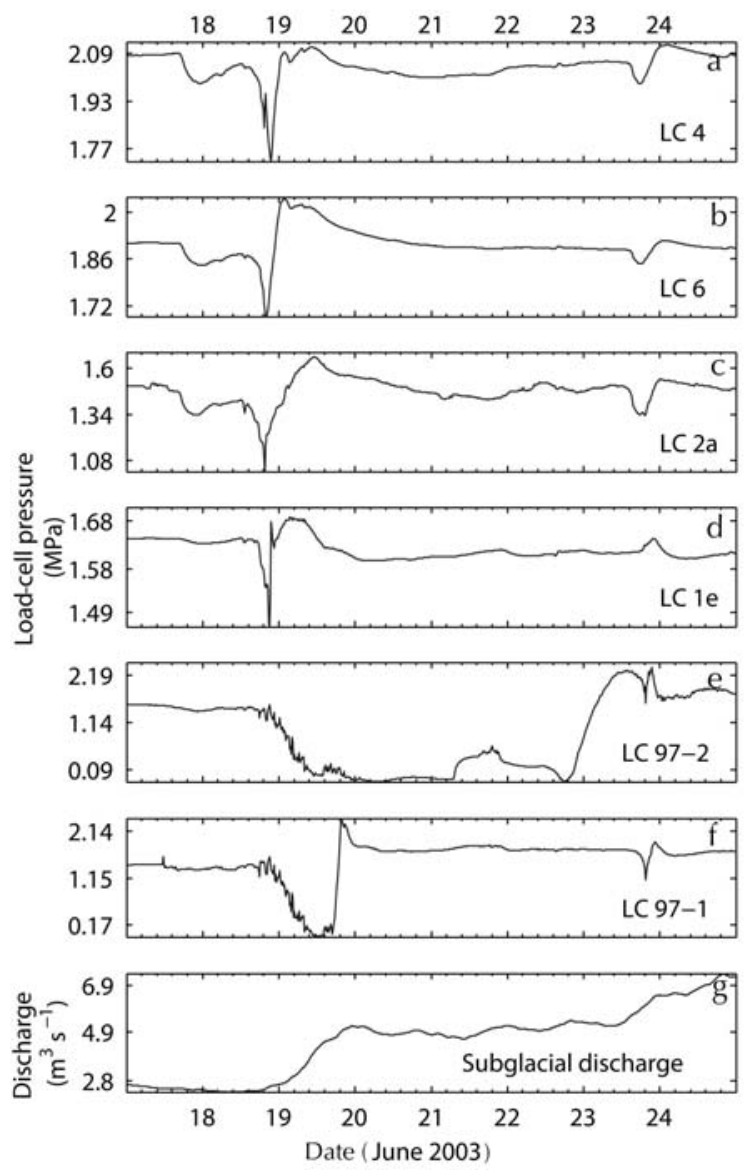

Fig. 9. A low-pressure event on load cells 97-1 and 97-2 in June 2003. (a-f) Load-cell pressure. (g) Subglacial discharge. Note the different $y$-axis scales.

higher than the pre-event value. Similarly, the pressure on the downstream load cell, LC 97-2, rose to 2.28 MPa after a low-pressure period of 4 days, though this load cell logged a more gradual increase than LC 97-1. We find similar overloads as the man-made cavities excavated with hot water are closing, and ice once again encroaches on the load cells.

\subsection{Observation summary}

We distinguish between global and local pressure events in the load-cell records. During a global event all load cells log a pressure drop and most, if not all, sensors act in phase. Local events are those that do not involve all load cells, sometimes even only one, and furthermore, they may be anticorrelated with each other (e.g. Fig. $7 d-f$ vs $g-h$ ).

There is a seasonal difference in the load-cell records. The winter regime is characterized by the following:

Few pressure events, but with relatively large amplitudes.

0-6 days lag between assumed forcing (surface input) and peaks of pressure event.

Mostly global events.

The summer regime has these characteristics:

Many pressure events, often on a daily basis.

Relatively more low-amplitude events.

No significant lag between forcing and pressure events.
Pressure events correlate with local maxima of the discharge derivative.

Some local events.

Extended periods of near-atmospheric pressure at individual load cells.

Pressure overloads around low-pressure zones.

Finally, the spring regime is characterized by:

High-pressure outbursts into the tunnel system.

Large-amplitude pressure events, compared to summer.

\section{INTERPRETATION AND DISCUSSION}

\subsection{Subglacial hydraulic systems}

We now briefly summarize the relevant features of subglacial drainage models of temperate glaciers, based on observations, measurements and theoretical developments over recent decades (e.g. Fountain and Walder, 1998).

\subsubsection{Thin water film}

It is commonly assumed that beneath temperate glaciers there exists a pervasive water film separating basal ice from the bedrock (e.g. Hindmarsh, 1996; Iverson and others, 2003; Schoof, 2004). The thickness and pressure in this thin water film (TWF) varies along the bed in accordance with normal stress variations in the ice, implying a small water flow from high to low pressures within the film. The film will be discontinuous, interrupted by subglacial drainage paths, cavities and sediments that are in direct contact with the bed. By far the most important disruption in the context of this paper will be the subglacial drainage ways.

\subsubsection{Linked-cavity system}

During winter, there is typically no surface water input, and the basal hydraulic system transports only stored water and bed-generated water. This water is thought to flow through a distributed or linked-cavity system. This is a slow-flowing system of overall high water pressure and low transmissivity, leading to a system with a high degree of connectivity (Fountain and Walder, 1998).

\subsubsection{R-channel system}

In summer, discharge is a few orders of magnitude larger than in winter, nearly all of which is due to surface melt and rainfall. Water is routed efficiently from the surface down to the glacier bed where high-flux channels grow at the expense of low-flux ones, implying an arborescent channel structure of low connectivity covering a rather small area of the bed (Röthlisberger, 1972).

\subsubsection{Connected vs unconnected systems}

Regardless of season, there are essentially two subglacial hydraulic systems: one connected to a drainage system (linked cavities and/or R channels) and the other unconnected (e.g. Murray and Clarke, 1995). An important consequence of the connected and unconnected system classification is that there is an anticorrelation between time-varying pressure signals in the two systems, a result of having to maintain the large-scale average pressure distribution of the ice overburden. That is, a pressure increment in the connected system above overburden leads to a negative 
pressure perturbation in the unconnected system. Murray and Clarke (1995) pointed out that the connected system, even over short distances, is highly heterogeneous, and that bed regions can rapidly switch back and forth between being connected and unconnected.

Likewise, Hubbard and others (1995) described how mechanical uplift around subglacial channels will force surface water into the unconnected areas surrounding the channel. Uplift is expected to occur if the water pressure in the connected system passes overburden. Iken and Truffer (1997) used isolated cavities to explain 'sticky spot' behaviour on hard-bedded glaciers. They claimed that isolated cavities would lose pressure when the sliding speed increases, thus effectively lowering the local shear stress. Following the connected-unconnected terminology the isolated cavities are parts of the unconnected system.

Weertman (1972) discussed the influence of stress bridging around the connected system on the unconnected system, showing that at low water pressures in the connected system, pressure on the bed along the channel wall will be larger than mean ice overburden, effectively sealing the channel from the unconnected system (Weertman, 1972, fig. 21b, p.327). In the case of an overpressurized connected system he found a pressure drop in the unconnected system (Weertman, 1972, fig. 22b, p. 328).

\subsection{Interpretation of results at Engabreen}

\subsubsection{What do the load cells measure?}

We infer the existence of a TWF (see section 5.1.1) at Engabreen from the following load-cell set-up: two load cells (LC 4 and 6) are located inside an overhang about $1 \mathrm{~m}$ deep and $1 \mathrm{~m}$ high at the lip, with LC 6 on the floor, and LC 4 in the roof just above (Figs 2 and 10). Without the ice in between, they would be facing each other, one pointing up, the other down. The pressure records from these two load cells show the same pressure variations and nearly the same pressure most of the time (e.g. Fig. 9). The only way to explain the fact that these two load cells correlate so well is that they measure the pressure in a water layer connecting them.

While total pressure measured by a load cell may also be affected by sediments in contact with the load cell's plate, our contention is that rapid changes in load-cell pressure (i.e. the pressure events we describe) can only be due to changes in water pressure in the TWF.

The water pressure registered by the load cell can be that of the TWF or the pressure within closed cavities or the pressure within an active drainage system. When it is that of the TWF or within cavities, the pressure will be a function largely of load-cell orientation and tilt (Table 1) and slidingspeed gradient. The water pressure in the TWF approximates the normal stress of the basal ice if we assume that the flow in the TWF is very small. Water pressure in the connected drainage system will be lower than in the TWF, by an amount that varies by the flux of water moving through the path, both diurnally and over longer timescales, by season.

\subsubsection{Critical hydraulic capacity}

Over-pressurizing the connected system will always force an anticorrelated pressure event in the unconnected system, independent of the time of year or the spatial distribution of the connected system. The dominant factor influencing communication between these two systems is the hydraulic capacity of the connected system. Using meteorological

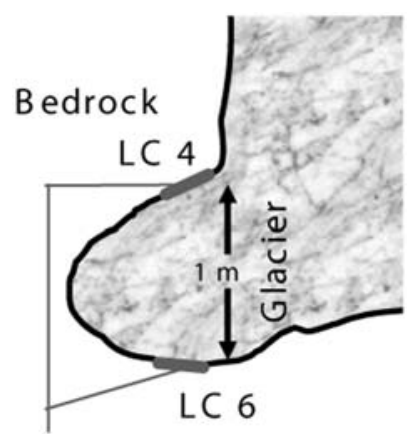

Fig. 10. The load cells LC 4 and LC 6 facing each other in an overhang. Ice flow is out of the page.

data to infer water inputs, and the tunnel discharge record to infer subglacial output, and comparing these with the loadcell records, we find that load-cell pressure events occur for variable water input and discharge volumes. In winter, pressure events occur for relatively small increases in water input (e.g. Fig. 7); the same increase would not force a pressure event during the summer. If we quantify the volume increments in terms of percentage we see that a discharge increase during winter with a corresponding largeamplitude pressure event (e.g. Fig. 7c) is of the order of $200 \%$, whereas a low-amplitude event in summer is forced by a small discharge increase of approximately $10-30 \%$. Thus, the capacity of the connected drainage system relative to the rate of water input acts as a controlling threshold for how much water the system can accommodate before it becomes over-pressurized and pressure events are recorded outside the connected system. This threshold will be called the 'critical hydraulic capacity'. A similar relation has been found on the soft-bedded Unteraargletscher, Switzerland (Gudmundsson, 2002).

The critical hydraulic capacity is governed by the recent water input history of the drainage system and is constantly changing due to the dynamics of the drainage system. In other words, even small inputs to a connected system of low hydraulic capacity (e.g. a linked-cavity system) can force pressure events in the unconnected system, whereas a larger input is needed to a connected system of higher hydraulic capacity (e.g. an R-channel system).

\subsubsection{Engabreen winter drainage system}

Evidence for the existence of a linked-cavity system during winter at Engabreen has previously been provided by a series of high-pressure pump experiments (Lappegard and Kohler, 2005). These pump tests indicated a drainage system under high pressure, with a high degree of spatial connectivity and low flux.

The winter load-cell records presented in this paper also point to a low-flux linked-cavity drainage system. During winter, the load cells mostly record the pressure of the unconnected system, that is, the TWF. In the case of a positive pressure perturbation due to a discharge increase beyond the critical hydraulic capacity of the connected system, global pressure events are recorded in the TWF (Fig. 7). The amplitude of these pressure events is overall large (Fig. 5). It is an expected result for drainage systems operating so close to capacity that a small change of volume produces a large positive pressure increment in the system (Clarke, 2005) with a successive uplift and cavity expansion 


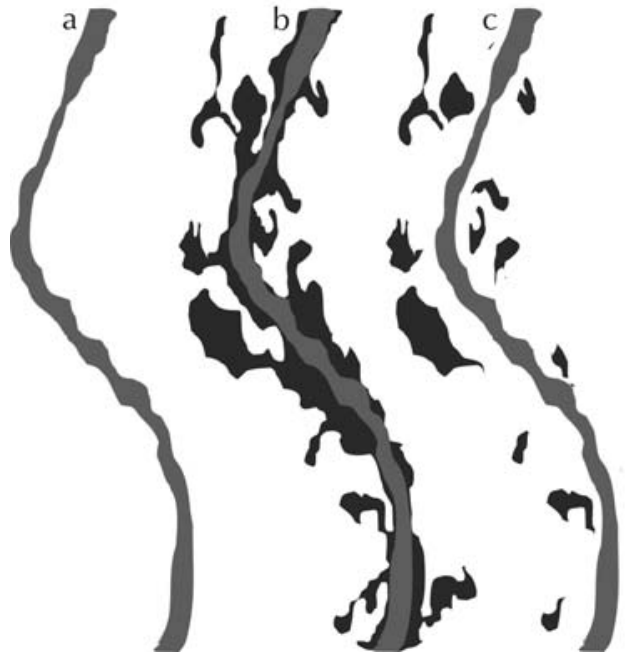

Fig. 11. (a) Channel at low pressure. (b) Pressurized channel. Shaded areas are flooded bed areas now connected. (c) Lowpressure channel with sealed-off cavities.

(Iken and others, 1983). Due to the large spatial extent of the linked-cavity system, this uplift is always seen as a global pressure event.

The relatively long time-lag of $0-6$ days between surface forcing and winter pressure events is mainly attributed to englacial infiltration processes, and represents the time required to reopen connections between the surface and the subglacial drainage system. On the surface of Engabreen, from about 950 ma.s.l. downward, much of the winter's snow drifts into the extensive crevasses, which extend from this point well down-glacier of the intakes at 840 m a.s.l. (Elvehøy and others, 1997). The time-lag also depends on the time since last reopening, such that two successive rain events, say 1-2 weeks apart, give the latter a 0-1 day lag between surface input and load-cell pressure event or discharge peak. Hagen and others (1993) reported a similar, although somewhat shorter, delay (2-3 days) at Bondhusbreen, at a location where the ice was $160 \mathrm{~m}$ thick.

\subsubsection{Engabreen summer drainage system}

At Engabreen, successive high-pressure pump experiments done in summer (Lappegard and Kohler, 2005) indicate a drainage system at low pressure, with high water fluxes, as well as a more limited spatial extent on the bed and a lower degree of connectivity than in winter. Periods with low pressure on LC 97-1 and 97-2 during summer (e.g. Fig. 9e and $f$ ) also attest to the presence of low-pressure channels. These low-pressure channels have a limited spatial extent, since the other load cells continue to log pressures around ice-overburden level. The low-pressure channels are sealed off by stress-bridging effects.

The summer load-cell records from Engabreen are best explained by the presence of two coexisting basal pressure regimes; one of $\mathrm{R}$ channels, the other, a system comprising poorly connected, or even unconnected, cavities and a TWF system, both at much higher pressures. When the R-channel system becomes over-pressurized due to discharge exceeding the critical hydraulic capacity, the stress bridge is overcome and communication between the two drainage systems becomes possible.
The amplitude of a pressure event during summer will depend on the degree of interconnectivity between the two different drainage systems within the connected system. Low-amplitude events are believed to be forced by small pressure increments in the connected system, whereas highamplitude events are forced by a larger pressure increment connecting more of the linked-cavity system with the R-channel system (larger area of the bed, similar to the winter events).

The correlation between a global pressure event and a local maximum in the derivative of the discharge curve (Fig. 6) can be explained by routing of water out of the R-channel system into 'storage' over wider areas of the bed. Such storage has previously been reported by Iken and others (1983) and Hubbard and others (1995).

A simple conceptual sketch of the evolution of the connected system is shown in Figure 11. Figure 11a shows a channel with low water pressure. Stress bridging seals the channel, and no exchange of water occurs between the channel and the surrounding bed areas. The varying crosssectional channel area is due to the different closure rates expected on an undulating bed with variable normal stress values. If water pressure in the channel increases, uplift will occur where $p_{\mathrm{w}}>\sigma_{\mathrm{nn}}$, (where $\sigma_{\mathrm{nn}}$ is the local normal stress at any point along the channel wall). Consequently, the surface area of the connected system can increase rapidly (Fig. 11b). As long as the water pressure remains high, the connected system will grow at the expense of the unconnected system. It is this 'storage' of water that causes the local maximum in the derivative of the subglacial discharge record (Fig. 6). Dead ends may develop in the unconnected system (fingering), resulting in large variability of cross-sectional area of the connected system. A similar conclusion has been reached by Schuler and others (2004) studying tracer transient velocities of subglacial channels.

As the water pressure decreases again, some of the water stored in dead ends can be sealed off from the connected system (Fig. 11c) (Iken and others, 1983). These isolated cavities will be classified as part of the unconnected system, but might at a later stage be incorporated in the linked-cavity system.

Iken (1981) derived the boundary at which uplift should occur, $p_{\text {crit }}<p_{\mathrm{i}}$. Iken's idea was that if $p_{\mathrm{w}}$ in the connected system exceeds $p_{\text {crit }}$ the glacier is lifted along the stoss sides of bed undulations. Water then flushes into areas of the bed that open up (lee sides). Schoof (2004) has shown that Iken's boundary is valid for general bed geometries using the local normal stress calculated along a general bed profile. Separation can occur if the normal stress equals the critical pressure. He showed that cavity pressure may differ from cavity to cavity, but that uplift will start as soon as the normal stress equals the lowest critical pressure.

Hubbard and others (1995) and Murray and Clarke (1995) both use the mean ice-overburden pressure as a limit for uplift of the connected system. We have no evidence of this being the case at Engabreen. Our load-cell and borehole measurements show that uplift occurs before the mean iceoverburden pressure is reached (Fig. 8). Assuming that Iken's critical pressure hypothesis (Iken, 1981) is correct, we should expect uplift if the water pressure in the connected system exceeds the local normal stress (Schoof, 2004) along the borders between the connected-unconnected systems. These borders will constantly move as the cross-sectional 
area of the basal drainage systems keeps adjusting to the non-steady basal water pressure.

We suggest that the discontinuous unconnected system is 'sealed off' from the connected bed areas as a function of the difference between normal stress along the border of the connected-unconnected systems and water pressure in the connected system. Consequently, bed areas of low normal stress will be flooded with connected water more frequently than areas of higher normal stress.

\subsubsection{Engabreen spring transition}

The transition from winter to summer drainage configuration, which occurs at Engabreen in late May or early June, is marked by a series of large-amplitude pressure events in the load-cell record and a few days with spatially pervasive high-pressure flow distributed over wide areas of the bed, as evidenced by the water pouring out of many of the tunnel boreholes. Following the Röthlisberger (1972) theory, if surface water inputs are maintained, disparate drainage paths coalesce to form more efficient lower-pressure $\mathrm{R}$ channels, with a more restricted, arborescent spatial distribution. The result is a discharge increase in the subglacial intakes of one or two orders of magnitude in just a few days (Fig. 4) and a gradual cutting-off of drainage through the many open tunnel boreholes as the system shifts from a predominantly linked-cavity system (with largeamplitude pressure events) to a dominating arborescent system (with small-amplitude pressure events).

\section{CONCLUSIONS}

Our load-cell transect is placed almost perpendicular to the sliding direction and covers a transect of $22 \mathrm{~m}$, a rather short distance compared with the glacier width $(1500 \mathrm{~m})$ or even the glacier thickness $(210 \mathrm{~m})$. Nevertheless, pressure changes that are repeatable over several seasons (as is the case with the data presented above) can be interpreted as major and common subglacial effects. Thus, subglacial effects that are repeatedly recorded by our load cells should also be expected on other hard-bedded, temperate glaciers.

This study has given insight into the relation between basal hydraulics and normal stress along the bed. Most of the bed sees static pressure around mean ice overburden interrupted by short-lived pressure drops of low amplitude. This somewhat contradicts the impression from surface boreholes on many glaciers, where subglacial pressures can vary from atmospheric to ice overburden on diurnal timescales.

Our data strongly suggest the existence of a TWF. The load cells appear to record the water pressure in the TWF, and this water pressure approximates the normal stress of the basal ice.

Stress bridging around low-pressure channels is recorded occasionally during summer. Stress bridging effectively seals off the low-pressure R-channel system, preventing it from collecting water at the bed. Interaction between an R-channel system and linked cavities is only possible when the stress bridge becomes removed, that is, when the R-channel system is pressurized.

We have found that uplift events occur before iceoverburden pressure is reached. Thus, we suggest the use of local normal stress as the limiting threshold, not the conventional ice-overburden pressure.
Furthermore, the hydraulic capacity of the subglacial discharge system is a variable that depends on the discharge history of the system and is therefore constantly changing. It appears that uplift of the connected system occurs if the amount of water routed through the system passes the critical hydraulic capacity. For that reason, a small surface input during periods of low hydraulic capacity (typically early spring) may force an uplift, whereas a much larger surface input is needed during periods of high hydraulic capacity to achieve the same result.

\section{ACKNOWLEDGEMENTS}

This work was supported by a grant from the Norwegian Research Council, by the Norwegian Water Resources and Energy Directorate, and by the hydropower company Statkraft. G. Lappegard thanks C. Schoof for discussions on TWFs and T. Schuler for lengthy and valuable discussions in general. We are grateful to the two reviewers $\mathrm{G}$. Flowers and $\mathrm{N}$. Humphrey for copious and detailed comments on an earlier version of this paper. Finally, scientific editor J. Walder helped us to structure and clarify the paper considerably.

\section{REFERENCES}

Boulton, G.S., E.M. Morris, A.A. Armstrong and A. Thomas. 1979. Direct measurement of stress at the base of a glacier. J. Glaciol., 22(86), 3-24.

Clarke, G.K.C. 2005. Subglacial processes. Annu. Rev. Earth Planet. Sci., 33, 247-276.

Cohen, D. 2000. Rheology of ice at the bed of Engabreen, Norway. J. Glaciol., 46(155), 611-621.

Cohen, D., R.LeB. Hooke, N.R. Iverson and J. Kohler. 2000. Sliding of ice past an obstacle at Engabreen, Norway. J. Glaciol., 46(155), 599-610.

DiBagio, E. 2003. A case study of vibrating-wire sensors that have vibrated continuously for 27 years. Field Measurements in Geomechanics, 6th International Symposium on Field Measurements in Geomechanics. Lisse, Sweits and Zeitlinger.

Echelmeyer, K. and Z. Wang. 1987. Direct observation of basal sliding and deformation of basal drift at sub-freezing temperatures. J. Glaciol., 33(113), 83-98.

Elvehøy, H., N. Haakensen, M. Kennett, B. Kjøllmoen, J. Kohler and A. Tvede. 1997. Glasiologiske undersøkelser i Norge 1994 og 1995. NVE rapp. 19/97. Oslo, Norwegian Water Resources and Energy Directorate.

Fountain, A.G. and J.S. Walder. 1998. Water flow through temperate glaciers. Rev. Geophys., 36(3), 299-328.

Gordon, S. and 7 others. 2001. Borehole drainage and its implications for the investigation of glacier hydrology: experiences from Haut Glacier d'Arolla. Hydrol. Process., 15(5), 797-813.

Gudmundsson, G.H. 2002. Observations of a reversal in vertical and horizontal strain-rate regime during a motion event on Unteraargletscher, Bernese Alps, Switzerland. J. Glaciol., 48(163), 566-574.

Haakensen, N. 1998. Glasiologiske undersøkelser i Norge 1996 og 1997. NVE rapp. 20/98. Oslo, Norwegian Water Resources and Energy Directorate.

Hagen, J.O., B. Wold, O. Liestøl, G. Østrem and J.L. Sollid. 1983. Subglacial processes at Bondhusbreen, Norway: preliminary results. Ann. Glaciol., 4, 91-98.

Hagen, J.O., O. Liestøl, J.L. Sollid, B. Wold and G. Østrem. 1993. Subglacial investigations at Bondhusbreen, Folgefonni, Norway. Norsk Geografisk Tidsskrift, 47(3), 117-162. 
Hindmarsh, R.C.A. 1996. Cavities and the effective pressure between abrading clasts and the bedrock. Ann. Glaciol., 22, 32-40.

Hubbard, B.P., M.J. Sharp, I.C. Willis, M.K. Nielsen and C.C. Smart. 1995. Borehole water-level variations and the structure of the subglacial hydrological system of Haut Glacier d'Arolla, Valais, Switzerland. J. Glaciol., 41(139), 572-583.

Iken, A. 1981. The effect of the subglacial water pressure on the sliding velocity of a glacier in an idealized numerical model. J. Glaciol., 27(97), 407-421.

Iken, A. and R.A. Bindschadler. 1986. Combined measurements of subglacial water pressure and surface velocity of Findelengletscher, Switzerland: conclusions about drainage system and sliding mechanism. J. Glaciol., 32(110), 101-119.

Iken, A. and M. Truffer. 1997. The relationship between subglacial water pressure and velocity of Findelengletscher, Switzerland, during its advance and retreat. J. Glaciol., 43(144), 328-338.

Iken, A., H. Röthlisberger, A. Flotron and W. Haeberli. 1983. The uplift of Unteraargletscher at the beginning of the melt season a consequence of water storage at the bed? J. Glaciol., 29(101), $28-47$.

Iverson, N.R. and 6 others. 2003. Effects of basal debris on glacier flow. Science, 301(5629), 81-84.

Jackson, M. 2000. Svartisen subglacial laboratory. NVE rapp. 14/ 2000. Oslo, Norwegian Water Resources and Energy Directorate.

Jansson, P., J. Kohler and V.A. Pohjola. 1996. Characteristics of basal ice at Engabreen, northern Norway. Ann. Glaciol., 22, 114-120.

Kohler, J. 1998. The effect of subglacial intakes on ice dynamics at Engabreen. NVE rapp. 12/98. Oslo, Norwegian Water Resources and Energy Directorate.
Lappegard, G. and J. Kohler. 2005. Determination of basal hydraulic systems based on subglacial high-pressure pump experiments. Ann. Glaciol., 40, 37-42.

Murray, T. and G.K.C. Clarke. 1995. Black-box modeling of the subglacial water system. J. Geophys. Res., 100(B7), 10,23110,245 .

Rea, B.R. and W.B. Whalley. 1994. Subglacial observations from Øksfjordjøkelen, north Norway. Earth Surf. Process. Landforms, 19(7), 659-673.

Röthlisberger, H. 1972. Water pressure in intra- and subglacial channels. J. Glaciol., 11(62), 177-203.

Schoof, C. 2004. The effect of cavitation on glacier sliding. Proc. $R$. Soc. London, Ser.A, 461(2055), 609-627.

Schuler, T., U.H. Fischer and G.H. Gudmundsson. 2004. Diurnal variability of subglacial drainage conditions as revealed by tracer experiments. J. Geophys. Res., 109(F2), F02008. (10.1029/2003JF000082.)

Smart, C.C. 1996. Statistical evaluation of glacier boreholes as indicators of basal drainage systems. Hydrol. Process., 10, 599-613.

Stone, D.B. and G.K.C. Clarke. 1996. In-situ measurements of basal water quality and pressure as an indicator of the character of subglacial drainage systems. Hydrol. Process., 10(4), 615-628.

Tulaczyk, S.M., B. Kamb and H.F. Engelhardt. 2000. Basal mechanics of Ice Stream B, West Antarctica. II. Undrainedplastic-bed model. J. Geophys. Res., 105(B1), 483-494.

Vivian, R. and G. Bocquet. 1973. Subglacial cavitation phenomena under the Glacier d'Argentière, Mont Blanc, France. J. Glaciol., 12(66), 439-451.

Weertman, J. 1972. General theory of water flow at the base of a glacier or ice sheet. Rev. Geophys. Space Phys., 10(1), 287-333.

MS received 22 April 2004 and accepted in revised form 18 November 2005 